\title{
MUHAMMAD SAW. DAN PELETAKAN DASAR PERADABAN ISLAM
}

\author{
R. H. Tamimi \\ Universitas Islam Negeri Sunan Kalijaga, Yogyakarta \\ Budy Sugandi \\ Marmara University, Turki \\ budy_oss@yahoo.co.id \\ Ismail Suardi Wekke \\ Sekolah Tinggi Agama Islam Negeri Sorong, Indonesia \\ ismailsuardi@yahoo.com
}

\begin{abstract}
The history of pre and post of Islamic civilization in Arabia is certainly bipolar condition. In one side, pre-Islamic civilization occurred worst behaviors such as hostility, discord, injustice, and the suppression which deconstructed tradition in the Arab nation. Of course, it was different when Muhammad (Arabic descent) was born, there was a very significant changes from the scientific case, social, economic, and other aspects. Overall, all of aspects above has been reconstructed by the miracles of the Prophet, i.e. that is holy Qur'an as a basic guidelines and in the form of Prophet behaviors, sayings and way of life which accumulated in the Hadith was capable of shifting civilization that backward into a very advanced civilization in any lines. This research tries to construct and compare the Arab civilization, pre-prophets born to Prophets had been born and brought revolutionary mission with the emergence of a new civilization, the Islamic civilization.
\end{abstract}

Keywords: Arabia pre-Islamic, the life of Muhammad, Islamic Civilization

\begin{abstract}
Abstrak. Sejarah pra-Islam dan pasca datangnya nabi Muhammad di tengah peradaban bangsa Arab tentunya merupakan suatu kondisi yang sangat bipolar. Di satu sisi, peradaban pra-Islam banyak terjadi perilaku buruk seperti permusuhan, perselisihan, ketidakadilan, penindasan bahkan pembunuhan merupakan suatu tradisi dekonstruktif dalam tatanan bangsa Arab. Tentunya, hal ini sangat berbeda ketika Muhammad saw. (keturunan Arab) lahir, terjadi perubahan tatanan yang sangat signifikan mulai dari konsteks keilmuan, sosial, ekonomi, dan aspek-aspek lainnya. Secara kompeherensif, aspek tersebut di atas direkonstruksi dari mukjizat nabi, yakni Alquran sebagai pedoman dasar dan berupa dari tata cara berperilaku nabi, ucapan dan way of life nabi yang terakumulasi dalam hadits mampu menggeser peradaban yang terbelakang menjadi perabadan yang sangat maju di berbagai lini. Penelitian ini mencoba untuk mengkonstelasikan dan mengkomparasikan peradaban bangsa Arab pra Nabi hingga Nabi dilahirkan dan membawa misi revolusioner dengan munculnya peradaban baru, peradaban Islam.
\end{abstract}

Kata Kunci: Arab pra-Islam, kehidupan Muhammad, Peradaban Islam 


\section{Pendahuluan}

Memperbincangkan

sosok

Muhammad saw. merupakan hal yang tidak ada habisnya. Begitu luas dan beragamnya tulisan para sejarawan baik Timur maupun Barat juga belum bisa dikatakan final dalam mengupas sosok nabi terakhir ini. Kepribadiannya yang memiliki dua sisi sebagai Rasul dan sebagai manusia biasa memunculkan diskusi lebih panjang lagi. Beberapa tokoh sangat sensitif dan terkesan bernada sinis dalam memahami sosok tersebut, sedangkan beberapa tokoh lainnya sangat simpatik bahkan di antaranya sangat antusias dalam mengungkapkan nilai-nilai positif dakwah Muhammad saw.

Menurut Arnold Toynbee, seorang Professor sejarah University of London, di luar kegemilangannya dalam mereformasi bangsa Arab, keberhasilan Muhammad saw. dalam membangun masyarakat Islam tidak terlepas dari cara kekerasan melalui peperangan dan pajak yang dipaksakan kepada pemeluk Yahudi. ${ }^{1}$ Argumen Toynbee ini kemudian dikritik oleh orientalis lainnya seperti Karen Armstrong yang menyatakan bahwa banyak orang telah gagal memahami sosok Muhammad saw. yang reformis dan visioner. $^{2}$ Namun Armstrong bukannya membela seratus persen sosok Muhammad, ia lebih memposisikan dirinya sebagai peneliti objektif. Ia pun tidak lepas dari kritik Oksidentalis tentang argumennya yang terburu-buru dalam memahami sosok Muhammad saw. dalam perspektif sejarah. ${ }^{3}$

\footnotetext{
${ }^{1}$ Arnold Tounbee, Sejarah Umat Manusia terj. Agung Prihantoro dkk. (Yogyakarta: Pustaka Pelajar, 2007), h. 484.

2 Karen Armstrong, Muhammad, Prophet for Our TimeYuliani Liputo (Bandung: Mizan, 2013), h. 230.

${ }^{3}$ Karen Armstrong banyak dikritisi tentang argumennya dalam mendefinisikan Jibril sebagai jin. Terlebih Jin dalam tulisannya iagambarkan sebagai sosok yang menyesatkan para petapa
}

Di luar perdebatan dua tokoh tersebut, muncul hal yang menarik ketika seorang non-Muslim yang merupakan Guru Besar di perguruan tinggi Maryland, America melakukan penelitian tokoh dunia dengan merangkai klasifikasi dari 100 tokoh terbaik dan paling berpengaruh sepanjang sejarah. Setelah merangkum biografi tokoh dari berbagai belahan dunia dan dari masa ke masa, ia memposisikan Muhammad saw. sebagai sosok yang menempati pemuncak klasifikasi, bahkan pengaruh Muhammad saw. dinilai lebih kuat jika dibandingkan dengan Nabi Isa (Jesus) yang menempati posisi ke tiga setelah Isaac Newton. ${ }^{4} \mathrm{Hal}$ ini tentu di luar dugaan. Banyak hal yang perlu digali lebih lanjut. Beberapa poin penting dari sosok Muhammad saw. termasuk ide visionernya juga dapat dijadikan acuan dalam kehidupan saat ini.

Tulisan ini merupakan salah satu upaya untuk melakukan pendalaman studi tentang sosok Muhamamd saw. dalam perspektif sejarah terutama peran beliau dalam peletakan dasar peradaban Islam. Berangkat dari hal di atas, terdapat beberapa poin yang menjadi kerangka studi lanjutan dalam mencermati sosok Muhammad. Beberapa poin tersebut sebagaimana tercermin dari rumusan masalah di bawah ini:

1. Bagaimana konteks bangsa Arab yang menjadi lingkungan hidup Muhammad saw.?

hira. Terlebih, kritikan juga dilontarkan oleh Jalaluddin Rahmad tentang gagasan Armstrong yang terburu-buru terutama dalam pengutipan Hadis yang tidak sahih. Lihat "Simpatik tapi Tidak Kritis", dalam Karen Armstrong, Muhammad, Prophet for Our TimeYuliani Liputo (Bandung: Mizan, 2013), h. 16.

${ }^{4}$ Michael H. Hart, The 100 Ranking of The Most Influential Persons in History (A Citadel Press, 1992), h. 3. 
2. Bagaimana sosok Muhammad saw. sebagai seorang Nabi dan sebagai manusia 'Arab (orang Arab)?

3. Bagaimana proses peletakan dasar peradaban Islam yang dibangun oleh Muhammad saw.?

\section{Konteks Bangsa Arab Pra-Islam}

1. Kondisi Geografis Jazirah Arabia

Jazirah Arab berada di bagian barat daya Asia. Sebuah semenanjung terbesar dalam peta dunia. Wilayah ini memiliki luas $1.745 .900 \mathrm{~km}$ dengan deretan padang pasir yang menjadi ciri khas dataran ini. Semenanjung ini berbatasan dengan Teluk Oman dan Teluk Persi (Teluk Arab) di sebelah timur, Laut Merah di sebelah barat, Lautan India di sebelah selatan, serta Irak dan Syiria di sebelah Utara. Meskipun daerah ini merupakan daerah yang dikelilingi laut, namun hampir 5/6 daerahnya merupakan padang pasir atau sahara yang tandus dengan luas seakan tak terbatas serta tidak tampak ada tumbuhtumbuhan yang rindang di kebanyakan daerah ini. ${ }^{5}$

Para ahli geologi menyatakan bahwa pada mulanya wilayah ini menyatu dengan Gurun Sahara sebelum terpisah oleh lembah Nil dan Laut Merah. Kawasan berpasir tersebut tersambungmenyambung mulai dari Asia melalui Persia bagian tengah sampai menuju ke Gurun Gobi di Cina. Selama priode

5 Ahmad Amin, Fajr al-Islam, cet. ke-11 (Kairo: Maktabah an-Nahdhah al-Misriyyah, 1975), h. 1-2.

${ }^{6}$ Philip K. Hitti, History of The Arabs terj. R. Cecep Lukman Yasin dan Dedi Slamet Riyadi. (Jakarta: Serambi, 2010), h. 16-17.

${ }^{7}$ Philip K. Hitti, History of The Arabs ..., h. tertentu dalam abad es, wilayah ini merupakan padang rumput yang bisa dihuni karena pencairan es tidak pernah mencapai lebih jauh dari bagian selatan pegunungan Asia kecil. ${ }^{6}$

\section{Kondisi Ekonomi Bangsa Arab}

Selain kebiasaan berburu para badui yang nomaden, perekonomian bangsa Arab terpengaruhi oleh persentuhan aktivitas dagang dari luar. Peradaban bangsa Arab terbangun dari tradisi perdagangan yang membuka jalinan hubungan dengan daerah sekitarnya (Persia, India, dan Cina) dengan komoditas dagang seperti mutiara, emas, dan sutera. ${ }^{7}$ Situasi surutnya pelayaran Laut Merah mengakibatkan terbukanya jalur perjalanan darat melalui Hijaz yang merupakan rute perjalanan di musim panas dan melalui Yaman dan Syam di musim dingin. 8

Dari jalan yang menghubungkan wilayah utara dan selatan, ramainya kafilah-kafilah yang berkendaraan unta dalam dinamika laju perdagangan internasional saat itu dapat menggeser perdagangan Bahrain, antara Kota Aden lama dan dua teluk (Swiss dan Aqabah). Orang Arab Hijaz, terutama Arab Quraisy memanfaatkan jalur ini bahkan karena faktor jalur perdagangan darat inilah yang membuat Kota Mekkah menjadi salah satu kota penting sebagai tempat transit bagi para kafilah. Tidak hanya itu, ibadah haji yang merupakan bentuk ritual keagamaan sejak zaman Nabi Ibrahim dan sudah

${ }^{8}$ Alquran melukiskan perjalanan ini dalam QS. Al-Quraisy 106:1-4. Perjalanan ini secara

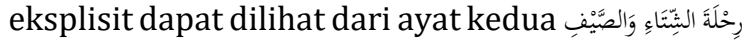
"perjalanan musim dingin dan musim panas" surat ini menggambarkan bahwa orang-orang Quraisy memiliki suatu tradisi, yakni perjalanan dagang. 
dikenal oleh masyarakat kuno, juga memiliki kontribusi terhadap besarnya peran Kota Mekkah. Haji dapat mendatangkan keuntungan ekonomi yang lumayan besar. Biasanya para saudagar Quraisy mengambil kesempatan ini dengan berdagang di wilayah Hijaz. ${ }^{9}$

\section{Kondisi Sosial Budaya Bangsa Arab}

Bangsa Arab kurang mengembangkan tradisi baca-tulis. Orang Arab akan berbangga dengan kekuatan daya hafal yang dimilikinya. Kondisi inilah yang menyebabkan mereka dijuluki bangsa yang buta huruf 'ummiy. sekalipun demikian, hal ini bukan berarti membuatbangsa Arab buta terhadap sastra. Banyak syair dan karya besar tercipta dan mewarnai sejarah kesusastraan Bangsa Arab. Lambat laun budaya tulis-menulis mulai mengalami perkembangan. Selain dari faktor internal, tradisi tulis bangsa Arab juga dipengaruhi oleh faktor eksternal, menurut Gabriel Said Reynolds, perkembangan tulis Arab terpengaruhi oleh dua hal, yakni persentuhan dengan Roma dan misionaris kristiani. ${ }^{10}$

Meski bangsa Arab tertinggal beberapa langkah dalam hal tulis-menulis, namun bangsa ini kaya dengan ribuan syair yang terlahir sebagai ungkapan pikiran, pengetahuan, dan pengalaman hidup. kumpulan syair ini dinamakan dengan diwan. Bentuk sastra yang dimiliki bangsa Arab juga cukup variatif, di antaranya berupa nasr (prosa), amsal (perumpamaan), khitabah (pidato) dan

9 Hasan Ibrahim Hasan, Sejarah dan Kebudayaan Islam (Jakarta: Kalam Mulia, 2001), h. 111.

${ }^{10}$ Gabriel Said Reynolds, The Quran in Its Historical Context (Canada: Routledge, 2008), h. 57.

${ }^{11}$ Ahmad Badrut Tamam, "Perlindungan lain sebagainya. Seiring dengan ramainya perdagangan internasional, Hijaz menjadi tempat berkumpulnya penyair-penyair dari berbagai penjuru. Kegiatan merangkai dan membacakan syair-syair di depan umum dilakukan di suatu pasar yang disebut 'Ukaz. Di antara syair-syair yang terpilih sebagai syair terbaik kemudian digantungkan di dindingdinding Kabah (syair-syair ini disebut mu'allaqat). Hal tersebut dilakukan sebagai bentuk apresiasi kepada orang yang menciptakan syair tersebut. ${ }^{11}$

Dalam segi organisasi koloni, bangsa Arab mengenal berbagai istilah perkumpulan masyarakat. Perkumpulan yang terkecil ialah masyarakat tenda yang disebut hayy, dari perkumpulan beberapa hayy membentuk komunitas klien (qaum), dan dari perkumpulan klien membentuk suku (qabilah).12 Istilah-istilah ini merupakan bentuk pola organisasi masyarakat bangsa Arab saat itu.

Tidak jauh berbeda dengan sudut pandang organisasi masyarakat, sebelum itu, jika dilihat dari segi peradaban dan pemukimanya, bangsa Arab biasa dibagi dua istilah, yakni Hadharah (kota menetap) dan Badawah (nomaden baduwi). Menurut Ibnu Khaldun pada mulanya bangsa Arab merupakan bangsa nomaden yang berpindah dari satu tempat ke tempat yang lain hanya untuk memenuhi kebutuhan jangka pendek mereka sehari-hari, sampai akhirnya kebutuhan pun semakin meningkat dengan upaya mereka memenuhi kebutuhan hidup jangka panjangnya, karena merasa dengan memanfaatkan

Anak dalam Perspektif al-Quran", Tesis Pasca Sarjana Universitas Islam Negeri Sunan Kalijaga Yogyakarta, 2012, h. 34.

12 Philip K. Hitti, History of The Arabsterj. R. Cecep Lukman Hakim dan Dedi Slamet Riyadi (Jakarta: Serambi, 2010), h. 32. 
buruan dan tumbuhan tidaklah mencukupi kebutuhannya, maka mereka memulai sistem produksi dengan berternak dan bertani. ${ }^{13}$ Bangsa Arab yang menetap pada akhirnya beranakpinak dan mulai mengalami penguatan ras yang sering mereka istilahkan dengan nasab. Penguatan nasab ini tercermin dalam penggunaan 'alam kuniyyah atau nama yang turut menyebutkan garis keturunan biasanya diistilahkan dengan menyandarkan garis keturunan lakilaki. ${ }^{14}$

\section{Kondisi Politik Bangsa Arab}

Bangsa Arab diapit oleh dua kerajaan besar. Letaknya yang sangat strategis sebagai kawasan penyangga mengakibatkan wilayah ini dijadikan perebutan dalam mempertahankan kekuasaan politik di Timur Tengah oleh dua imperium raksasa yakni Bizantium dan Persia. ${ }^{15}$ Karena wilayah Arab dikelilingi oleh gurun pasir tandus dan masyarakatnya hidup secara nomaden (berpindah-pindah) mengakibatkan Bangsa Arab sulit untuk dikendalikan. Dalam catatan Rippin, terdapat dua hal yang mewarnai persaingan politik di Jazirah Arab, pertama adalah persaingan dua imperium Romawi dan Persia dan kedua adalah persaingan antara Yahudi, Sekte Nasrani, dan pengikut Zoroaster. ${ }^{16}$

13 Ibn Khaldun, Muqaddimah terj. Ahmadie Thoha (Jakarta: Pustaka Firdaus, 2011), h. 142.

14 Muhammad Barir, "Buruh dan Perbudakan dalam Perspektif al-Qur'an” dalam alQuran dan Isu-Isu Sosial (Yogyakarta: Idea Press, 2014), h. 109.

15 Taufiq Adnan Amal, Rekonstruksi Sejarah al-Qur'an (Yogyakarta: FKBA, 2001), h. 9.

16 Fahruddin Faiz, Hermeneutika al-Quran: Tema-Tema Kontroversial (Yogyakarta: eLSAQ Press, 2011), h. 72
Bangsa Arab yang bermukim di gurun pasir secara terpisah mengakibatkan kehidupan mereka diselimuti oleh mara bahaya. Untuk itu mereka membangun sistem perlindungan kesukuan yang biasanya disandarkan pada garis keturunan. Dari hal ini pulalah lahir solidaritas kesukuan (ashabiyah). Setiap suku akan melindungi anggotanya tanpa peduli salah maupun benar. ${ }^{17}$ Kondisi perpolitikan internal bangsa Arab terutama bani Quraisy ${ }^{18}$ banyak diwarnai berbagai perebutan kekuasaan dan perselisihan. Ketika Abd Dar meninggal, saat itu terjadi perebutan penguasaan Makkah antara bani Abdu Dar dengan bani Abdu Manaf. Ada lima hal yang diperebutkan oleh para bani yakni siqayah (Pengelolaan Air) dan rifadah (Perpajakan dan Penyantunan Masyarakat Miskin) yang jatuh ketangan Bani Abdu Manaf serta liwa' (Kebijakan Perang), hijabah (Pemegang Kunci Kabah), dan Dar anNadwa (Tempat Perkumpulan) yang jatuh pada Bani Abdu Dar. ${ }^{19}$ Pada masa selanjutnya kepemimpinan rifadah dan siqayah dipegang Hasyim dan setelah Hasyim meninggal, terjadilah perselisihan antara Muthalib dengan Umayyah. Perselisihan ini terus berlanjut sampai akhirnya Air zam-zam berhasil ditemukan dan Abdul Muthalib menjadi pengendali suku lainnya. ${ }^{20}$

17 Karen Armstrong, Muhammad, Prophet for Our Timeterj. Yuliani Liputo (Bandung: Mizan, 2013), h. 44.

18 Pendiri bani Quraisy yang pertama adalah Qus\}ai bin Kilab, ia mulai meletakan garis keturunan nasabnya pada $480 \mathrm{M}$ kemudian dilanjutkan oleh Hasyim dan Abdullah Muthalib. Lihat Khalil Abd al-Karim, Hegemoni Quraisy terj. M. Faishol Fatawi(LKiS: Yogyakarta, 2012), h. 2.

${ }^{19}$ Aksin Wijaya, Arah Baru Studi Ululumul Qur'an (Yogyakarta: Pustaka Pelajar, 2009), h. 25.

20 Aksin Wijaya, Arah Baru Studi Ulumul Quran ..., 2009) h. 25. 
5. Kondisi Kepercayaan Bangsa Arab

Kebanyakan masyarakat Arab adalah penganut agama Watsani (penyembah berhala). Menurut sebagian pendapat, penyebar agama Watsani pertama di tengah-tengah masyarakat Arab adalah Amr bin Luhay al-Khuza'i. dia merupakan orang yang membawa patung dari Syam ke Kabah. Hal ini bermula ketika ia sakit parah. Saat itu ia mendengar bahwa di alBalqa' (sebuah nama daerah di Syam) terdapat sebuah mata air panas yang dikatakan dapat menyembuhkan berbagai penyakit. Ia pun memutuskan untuk mendatanginya dan mandi di sumber mata air tersebut kemudian akhirnya ia sembuh. Karena masyarakat di sekitar mata air itu menyembah patung, iapun bertanya mengenai alasan mereka. Sampai akhirnya ia tahu bahwa patungpatung tersebut merupakan sesembahan masyarakat untuk meminta pertolongan dan hujan. Ia pun tertarik dan meminta satu di antara patung-patung tersebut untuk dibawa pulang. ${ }^{21}$

Tiap suku Makkah biasanya memiliki berhalanya masing-masing yang berbeda antara satu suku dengan suku lainya dan masing-masing suku meletakkan berhalanya di sekitar Kabah. Menurut sejarawan, berhala-berhala ini sampai mencapai angka 360 lebih.22 Banyaknya berhala ini tentunya menjadi simbol tentang ego dan fanatisme kepercayaan bangsa Arab. Sebagaimana yang

${ }^{21}$ Hasan Ibrahim Hasan, Sejarah dan Kebudayaan Islam (Jakarta: Kalam Mulia, 2001), h. 123.

${ }^{22}$ Asghar Ali Engineer, Islam dan Teologi Pembebasan terj. Agung Prihantoro (Yogyakarta: Pustaka Pelajar, 2009), h. 42.

${ }^{23}$ Choirul Rofiq, Sejarah Peradaban Islam (Ponorogo: STAIN Ponorogo Press, 2009), h. 29.

${ }^{24}$ Beberapa daerah di Jazirah Arabia seperti Yaman karena berada dalam kekuasaan kerajaan Aksum yang Kristen hingga 571 M sangat diketahui, ada empat berhala yang dikenal dalam tradisi Arab, pertama yaitu Latta yang merupakan dewa tertua yang terletak di Thaif, 'kedua 'Uzza yang bertempat di Hijaz, ketiga adalah manah yang bertempat di Yasrib (sekarang Madinah), dan keempat adalah Hubal yang dianggap sebagai dewa terbesar yang berada di Kabah. ${ }^{23}$

Agama lain yang juga patut diperhitungkan dalam lintas sejarah bangsa Arab adalah agama Yahudi dan Kristen. Menurut Arnold Toynbee, masuknya Yudaisme pertama kali adalah dibawa oleh pengungsi perang antara Roma dengan Yahudi pada tahun 66 hingga 70 M. Kemudian keyakinan ini mulai meraih banyak pemeluk di Kawasan Hijaz ialah pada tahun 132 hingga $135 \mathrm{M}$ tepatnya di Oasis Tayma', Khaibar, Yasrib, dan Yaman. Capaian Yudaisme ini kemudian diikuti oleh agama Kristen yang mulai meraih pemeluk agama pada tahun $523 \mathrm{M}$ akibat faktor pengaruh Roma dan Persia. $^{24}$

\section{Sosok Muhammad Saw. sebagai Nabi dan Manusia 'Arab (orang Arab)}

Salah satu langkah untuk mengetahui posisi Muhammad saw. sebagai Nabi dan manusia 'Arab (orang Arab) adalah dengan menelusuri rekam jejak perjalanan hidup beliau dari masa ke masa. Muhammad saw. lahir pada tahun $570 M^{25}$ bertepatan dengan hari Senin

mempengaruhi kondisi keberagamaan masyarakat. Arnold Tounbee, Sejarah Umat Manusia terj. Agung Prihantoro dkk. (Yogyakarta: Pustaka Pelajar, 2007), h. 479.

25 Beliau lahir pada tanggal 20 Agustus. Tahun kelahirannya masih diperdebatkan oleh sebagian sejarawan antara 570, 571, dan 572. Seorang ahli ilmu falaq menyebut tahun kelahiran Muhammad SAW yang tepat adalah 571 tepatnya 20 April 571. Lihat Hasan Ibrahim Hasan, Sejarah 
tanggal 12 Rabi' al-Awwal. Tahun kelahiran beliau sering dikenal dengan tahun gajah. Sebutan ini merepresentasikan sebuah peristiwa serbuan Abrahah (Gubernur Yaman) yang hendak menghancurkan Kabah. Ia yang saat itu mengendarai Gajah gagal menuju Kabah karena alasan misterius. ${ }^{26}$ Pemeluk Islam meyakini bahwa kegagalan Abrahah diakibatkan oleh serangan burung ababil yang menjatuhkan kerikil dari neraka sebagai serangan kepada Abrahah dan bala tentaranya. Sedangkan beberapa pemikir kontemporer menyatakan bahwa kegagalan Abrahah menuju Kabah adalah disebabkan serangan virus berupa mikroba yang mematikan. ${ }^{27}$

Muhammad saw. lahir sebagai seorang yatim. Ayah beliau yang bernama Abdullah wafat ketika beliau masih dalam kandungan ibunya, Aminah. Beliau ketika masih bayi dititipkan pada asuhan Halimah untuk disusui dalam lingkungan masyarakat Arab pedesaan sebagaimana tradisi Quraisy. ${ }^{28}$ Pada sekitar usia enam tahun beliau dikembalikan kepada pangkuan kasih sayang ibundanya dan tak lama setelah itu ibundanya wafat dan lengkap sudah kondisi Muhammad saw. yang hidup tanpa orang tua. Untuk kehidupan Muhammad saw. kecil kemudian menjadi tanggung jawab sang kakek Abdul Muthalib. ${ }^{29}$ Tak lama dalam

dan Kebudayaan Islam (Jakarta: Kalam Mulia, 2001), h. 137.

26 Syahruddin el-Fikri, Situs-Situs dalam alQur'an (Jakarta: Republika, 2010), h. 94.

27 Abduh (1864-1905 M) menafsiri burung ababil dengan mikroba dalam Q.S. al-fil (105): 3. Lihat Abdul Mustaqim, "Kontroversi tentang Corak Tafsir Ilmi“ dalam Jurnal Studi Ilmu-Ilmu alQur'an dan Hadis vol. 7, (Yogyakarta, Jurusan Tafsir Hadis UIN Sunan Kalijaga, 2006), h. 30.

28 Karen Armstrong, Muhammad, Prophet for Our Time terj. Yuliani Liputo (Bandung: Mizan, 2013), h. 56. belaian sang kakek, Muhammad saw. kembali harus menerima kepergian orang terdekatnya itu (Abdul Muthalib) ketika Ia berusia delapan tahun. Untuk selanjutnya, kehidupan Muhammad saw. berada dalam pengawasan sang paman, Abu Thalib.

Bersama Abu Thalib, Muhammad saw. diajak berkelana dari negeri ke negeri yang lain untuk keperluan berdagang. Pada usia 12 tahun, Abu Thalib mengajak Muhammad saw. ke Syam, di tengah perjalanan ia dicegat oleh seorang pendeta bernama Buhairo ${ }^{30}$ dan diserukan untuk segera pulang. Buhairo menemukan tanda kenabian pada Muhammad saw. dan ia memberitahukan bahwa meneruskan perjalanan ke Syam dianggap akan membahayakan nyawa Muhammad saw.. Hal ini membuat Abu Thalib berbalik arah dan memilih tidak melanjutkan perjalanan.

\section{Muhammad saw. sebagai 'Arab (orang Arab)}

Sebagaimana kebanyakan masyarakat di sekitarnya, Muhammad kecil ketika berada dalam asuhan Halimah telah belajar menggembala kambing. Kesabaran dan ketelatenan sebagai seorang penggembala membangun mentalitas dan watak kepemimpinan dan sikap ini terbawa

29 Hasan Ibrahim Hasan, Sejarah dan Kebudayaan Islam (Jakarta: Kalam Mulia, 2001), h. 137.

30 Dalam beberapa literature nama Buhairo disebut dengan Bahiroh, ia melihat awan yang mengikuti perjalanan Muhammad dan pepohonan yang menunduk seolah memberikan sapaan hormat. Setelah Bahiro bertanya beberapa hal pada Muhammad dan melihat tanda kenabian pada punggungnya, ia yakin bahwa anak kicil bernama Muhammad ini merupakan Nabi yang dijanjikan akan datang. Lihat Syahruddin el-Fikri, Situs-Situs dalam al-Qur'an (Jakarta: Republika, 2010), h. 103. 
hingga Muhammad beranjak dewasa. ${ }^{31}$ Aktivitas menggembala juga menjadi dasar kepemimpinan. Tidak semua orang bisa melakukan hal ini. Tiap pagi menggiring gembalaan dan menuntun pulang ke kandang ketika sore hari menjelang. Hal ini melatih watak kepemimpinan dalam kemampuan menuntun dan mengendalikan rakyatnya sebagai kontrol sosial.

Muhammad saw. sebagaimana masyarakat pada umumnya juga memiliki aktivitas dan pencaharian dalam memenuhi kebutuhan sehari-hari. Etos kerja beliau terlihat dari keuletannya dalam kegiatan perniagaan. ${ }^{32}$ Masa kecil beliau banyak menghabiskan waktunya untuk menemani sang paman berjualan sampai ke negri Syam, menjumpai berbagai peristiwa dan fenomena yang membentuk pengalaman sosial. Diketahui bahwa pasar merupakan salah satu ruang publik yang di dalamnya berkumpul berbagai manusia dari berbagai golongan dengan watak yang beragam dan pasar juga mencerminkan pradaban suatu daerah pada masa itu.

Sebagai seorang laki-laki, Muhammad saw. melangsungkan pernikahan ketika usia 25 tahun. Khadijah binti Khuwailid yang saat itu terkagum-kagum terhadap kejujuran

31Hasan Ibrahim Hasan, Sejarah dan Kebudayaan Islam (Jakarta: Kalam Mulia, 2001), h. 138.

${ }^{32}$ Hasan Ibrahim Hasan, Sejarah dan Kebudayaan Islam ... h. 138.

${ }^{33}$ Hasan Ibrahim Hasan, Sejarah dan Kebudayaan Islam ... h. 140.

${ }^{34}$ Karen Armstrong, Muhammad, Prophet for Our Time terj. Yuliani Liputo (Bandung: Mizan, 2013), h. 58.

35Karen Armstrong, Muhammad, Prophet for Our Time terj. Yuliani Liputo (Bandung: Mizan, 2013), h. 57.
Muhammad saw. selama bersamanya dalam menjalankan bisnis melamar Muhammad saw.. Saat itu statusnya adalah seorang janda berusia 40 tahun. Dari pernikahan ini, Muhammad saw. dikaruniai dua putera (al-Qasim dan Abdullah) dan empat puteri (Zainab, Ruqayyah, Ummu Kulsum, dan Fatimah), di antaran putrinya, Fatimah kemudian dinikahi oleh Ali ibn Abi Thalib. ${ }^{33}$ Sedangkan kedua putera beliau meninggal sewaktu masih bayi. ${ }^{34}$

Sebagaimana orang Arab kebanyakan, gaya hidup Muhammad saw. mencerminkan lingkungannya. Dengan mengenakan jubah dan berjenggot beliau bisa berkomunikasi dengan masyarakat sekitar. ${ }^{35}$ Ketika beliau berada di tengah-tangah orang yang tinggi beliau tidak kelihatan lebih pendek dari mereka. Begitupun ketika beliau berada di antara orang-orang yang bertubuh pendek, beliau tidak kelihatan lebih tinggi dari mereka. Rambut beliau ikal sampai ke bahu, tidak terlalu lurus dan tidak pula terlalu keriting. ${ }^{36}$

Ketika beliau menikah dengan Khadijah, budaya perbudakan masih mentradisi dikalangan orang berada. Saat itu, Khadijah menghadiahkan kepada Muhammad saw. seorang budak bernama Zaid bin Harisah. tidak seperti

36 Hal ini sebagaimana dalam hadis "Telah menceritakan kepada kami Muslim telah menceritakan kepada kami Jarir dari Qatadah dari Anas dia berkata; "Nabi shallallahu 'alaihi wasallam adalah seseorang yang berlengan kekar, aku tidak pernah melihat orang yang menyerupainya, sedangkan rambut Nabi shallallahu 'alaihi wasallam ikal, tidak terlalu lurus dan tidak pula keriting."' Lihat Muhammad bin Isma'il bin Ibrahim bin al Mughirah bin Bardizbah, S\}ah\}ih\} Bukhari, No. 5455. CD Lidwa Pustaka. 
tuan kebanyakan, sikap lembut Muhammad saw. sangat dikagumi oleh Zaid dan ketika keluarga Zaid datang untuk menebusnya, Zaid enggan dan masih ingin tinggal bersama tuannya. Semenjak itu, Zaid diberi kebebasan dan diadopsi oleh Rasulullah. ${ }^{37}$

\section{Muhammad saw. sebagai Nabi}

Bagaimanapun Muhammad saw. beraktivitas, bergaul, dan bergaya hidup sebagaimana orang Arab kebanyakan, namun Muhammad saw. tetaplah memiliki keistimewaan yang tidak dimiliki oleh orang kebanyakan. Sebagai seorang Nabi pilihan Muhammad dianugerahi wahyu ilahiyah sebagai bentuk komunikasi dengan tuhan yang mentitahkan Islam kepada manusia. Selain itu, Nabi Muhammad juga memiliki mukjizat yang tidak dimiliki oleh orang pada umumnya. Salah satu mukjizat tersebut adalah Alquran sebagai mukjizat yang shalih li kulli zaman wa makan.

Nabi yang terikat dengan budaya Arab dan berinterakti dalam keseharian dianugerahi sifat ma'shum atau yang terhindar dari dosa. Di dalam jati diri beliau telah bersemayam sifat jujur, dapat dipercaya, pencerah, dan cerdas. Pada usia ke 35 tahun, Kabah yang mengalami kerusakan mulai diperbaiki oleh penduduk sekitar. Sampai selesai renovasi, hajar aswad yang masih tergeletak belum juga diletakan di dinding Kabah. Para pembesar saling bersaing mempromosikan diri untuk berkesempatan menjadi orang yang meletakakan batu hitam tersebut, namun

${ }^{37}$ Karen Armstrong, Muhammad, Prophet for Our Time terj. Yuliani Liputo (Bandung: Mizan, 2013), h. 59. perdebatan sengit mengakibatkan waktu terbuang.

Mereka belum menemukan orang yang cukup bijak untuk menyelesaikan permasalahan ini hingga muncul sebuah ide bahwa orang yang datang pertama kali memasuki Masjidil Haram melalui bab Syaibah (saat ini dinamakan bab asSalam) dianggap layak untuk memberi keputusan. Saat itu, seseorang yang pertama kali masuk ke Masjidil Haram adalah Muhammad saw.. Beliau kemudian membentangkan sorbannya, menaruh hajar aswad di atasnya, dan semua pembesar ikut merasakan membawa hajar aswad dengan menjinjingnya menuju dinding Kabah. Setelah mendekati permukaan Kabah, Muhammad saw. mengambil batu hitam tersebut untuk kemudian meletakkannya ditempat semula dan semua pun puas atas kebijaksanaan tersebut. ${ }^{38}$

\section{Peletakan Dasar Peradaban Islam yang Dibangun oleh Muhammad Saw.}

1. Pendidikan

a) Upaya Pengentasan Buta Huruf

Masyarakat Arab dikenal dengan masyarakat yang buta huruf. Kebanyakan penyair akan lebih bangga dengan pendayagunaan hafalannya dibandingkan dengan tulisan. Kedatangan Muhammad saw. ke Madinah di awal-awal masa kehijrah-annya membuat terbukanya kesadaran baru terhadap baca tulis. Madinah yang sebagian penduduknya merupakan orang Yahudi sedikit lebih maju dalam dunia tulis-menulis. Pertemuan antar dua budaya, Makkah dan

38 Hasan Ibrahim Hasan, Sejarah dan Kebudayaan Islam ... h. 140. 
Madinah membawa pada sudut pandang baru Rasulullah.

Saat Muhammad saw. memasuki Madinah, beliau melihat kaum Yahudi mengajari anak-anak baca tulis. Nabi pun kemudian tertarik dan menyuruh sepuluh orang di antara para sahabatnya untuk belajar pada orang Yahudi tersebut. di antara kesepuluh sahabat tersebut adalah Zaid bin Sabit, Manzur bin 'Amr, Ubay bin Ka'ab dan tujuh sahabat lainnya. ${ }^{39}$ Apa yang dilakukan Nabi merupakan sebuah pedoman semangat keilmuan. Kepada siapapun umat boleh belajar bahkan kepada pemeluk agama lain.

\section{b) Ahl as-Suffah dan Semangat Keilmuan}

Dari berbagai kalangan sahabat, $A h l$ as-Suffahmerupakan sekelompok kalangan yang bisa dikatakan cukup memiliki kedekatan dengan Nabi. Kedekatan ini tidak hanya kedekatan dhahiriyah karena mereka tinggal di emperan serambi Masjid Nabawi, namun juga kedekatan batiniyah karena perjumpaan batin mereka dengan Rasulullah. Kedekatan batin ini terepresentasikan ketika mereka berhijrah dari Makkah meninggalkan rumah, ternak, dan harta bendanya untuk ikut setia bersama Muhammad saw.

Di antara 70 orang dari Ahl as-Suffah adalah Abdullah Ibn Ummi Maktum, Bilal, dan Abu Hurairah ${ }^{40}$ yang benyak mencatat hadis Nabi dengan hafalannya. Walau Abu Hurairah (Abdurrahman bin Sakhra) bukan merupakan golongan yang pertama

39 Tim Departemen Agama RI, Ulum atTafsir I (Jakarta: Departemen Agama RI, 1996), h. 58.

40 Abdul Mu'in al-Hafni, Ensiklopedi Golongan, mazhab, pertain dan Gerakan Islam di seluruh Dunia Terj. Muhtarom (Jakarta: Grafindo, 2005), h. 97. kali masuk Islam, namun beberapa ulama sepakat tentang posisinya sebagai sahabat terbanyak dalam periwayatan hadis di luar berbagai kontroversinya. Fenomena Ahl as-Suffah ini bahkan digambarkan dalam Alquran surat al-Mujaddilah 58:11 serta dari mana inipulalah dikatakan istilah tasawwuf muncul. ${ }^{41}$

Ahl as-Suffah bukan merupakan golongan otoritatif, namun lebih golongan sukarela. Di tengah-tengah perkumpulan mereka Rasulullah berpidato dan menyampaikan banyak hal tentang ilmu yang beliau miliki termasuk Alquran dan hadis. Dari perkumpulan ini pula terbentuk wadah keilmuan dalam membangun tatanan masyarakat. Sahabat yang memiliki permasalahan maupun pertanyaan tentang suatu hal bisa langsung bertanya pada Rasulullah. Sebaliknya, Rasulullah pun bisa memantau secara langsung aktivitas sahabat beliau dan dapat memberikan masukan dan teguran kepada mereka jika melakukan hal-hal keliru.

\section{Sosial Budaya}

a) Penghapusan Perbudakan

Tidaklah kebetulan Islam dalam beberapa hukuman yang diberlakukan kepada mukallaf mengharuskan atas pembebasan budak. Pengangkatan derajat budak juga terlihat ketika bilal mengumandangkan azan, sebuah posisi yang terhormat. Muhammad saw. lebih memilih posisi itu untuk diisi oleh seorang mantan budak sebagai lambang kesetaraan. ${ }^{42}$ Dalam Alquran kata budak

41 Rosihon Anwar dan Mukhtar Shalihin, Ilmu Tasawwuf (Bandung: Pustaka Setia, 2007), h. 9.

${ }^{42}$ M. Quraish Shihab, Tafsir al-Mishbah vol. 13 (Jakarta: Lentera Hati, 2003), h. 260. 
sendiri diulang sebanyak 90 kali $^{43}$ dengan berbagai term baik antonim maupun yang sepadan dan kebanyakan mengacu terhadap pengentasan budak.

\section{b) Pemberian Harta Waris kepada Perempuan dan Pembatasan Poligami}

Datangnya Islam di Kawasan Arab juga memberikan dampak yang signifikan terutama dalam dekonstruksi budaya bias gender. Bayi wanita yang lahir dulu dianggap sebagai sebuah petaka dan bagi orang yang masih memegang tradisi jahiliyah akan tega menguburnya hiduphidup. Kedatangan Islam tidak sekedar merupakan gerakan sosial keagamaan namun juga gerakan kemanusiaan. Harta waris dan pembatasan istri merupakan salah satu upaya Islam mengangkat derajat wanita.

Dahulu wanita dan anak-anak tidak mendapatkan warisan. Bahkan dalam hubungan pernikahan, seorang laki-laki bisa memiliki istri lebih dari tujuh orang. Kedatangan Islam membangun budaya baru dengan membatasi jumlah istri cukup empat orang. Hal tersebut pada masa itu dianggap cukup adil mengingat posisi dan kedudukan perempuan yang sejak dulu tidak diperhatikan.

\section{c) Toleransi antar Agama}

Toleransi beragama yang paling terlihat selama dakwah Nabi Muhammad adalah ketika berada di Madinah. Nabi Muhammad saw. mulai meletakan dasardasar kehidupan sosial antar umat beragama. Menurut Munawir Syadzali, beberapa poin yang bisa digarisbawahi dari piagam Madinah adalah

مَلكَتَت أَيْمَانُكُمْ dan رقاب Fuad Abd al-Baqi, Mu'jam al-Mufahras li al-Fadh al-Quran (Beirut, Dar al-Fikr, 1981), 397. pembentukan ummat tamaddun (berperadaban) dan toleransinya dengan pemeluk agama lain meliputi: a) saling bertetangga baik, b) saling membantu dalam menghadapi musuh bersama, c) membela mereka yang dianiaya, d) saling menasihati, dan e) menghormati kebebasan beragama. ${ }^{44}$

\section{Ekonomi}

a) Riba dan Zakat Sebuah Upaya Pengentasan Kemiskinan

Beberapa orang dalam kebudayaan Arab berpencaharian sebagai pedagang. Nabi merupakan salah satu di antara sosok yang pernah masuk dan berada di tengah-tengah komunitas tersebut. Nabi juga sangat mengenal praktik riba dan untuk itu dibeberapa hadis dan Alquran riba menjadi salah satu tema yang dibahas. Penghapusan riba juga berkorelasi dengan upaya pengentasan kemiskinan. Selain penghapusan riba, Islam juga sangat memperhatikan praktik monopoli, untuk menanggulangi hal tersebut dan agar harta tidak berputar pada satu pihak, maka diberlakukanlah kewajiban zakat yang terdiri atas zakat mal dan fitrah.

\section{Kesimpulan}

Jika mencermati peradaban bangsa Arab pra-Islam dan ketika masa Rasulullah yang datang dengan mengusung agama Islam. Beberapa perbedaan dapat terlihat dengan jelas terjadi dalam beberapa aspek. Baik keilmuan, sosial, ekonomi, dan aspekaspek lainnya. Dari sini, salah satu keunggulan Islam adalah tentang ajarannya yang sangat kompleks dan

44 Dedi Supriyadi, Sejarah Peradaban Islam (Bandung: Pustaka Setia, 2008), h. 65. 
hampir mencakup semua hal yang berkaitan dengan kemanusiaan dan kesehariannya. Salah satu hal yang diperhatikan oleh Islam adalah posisi wanita dibawah laki-laki, harta waris dan berbagai hal-hal lain yang bias gender. Hal-hal tersebut merupakan di antara yang mengalami perubahan positif dengan kedatangan Islam.

Pengangkatan derajat budak juga merupakan sebagian aspek yang disoroti oleh Rasululah. Dalam beberapa hukum Islam dapat terlihat bahwa Islam tidak hanya ingin memberikan perhatian terhadap budak, namun juga ingin mengentaskan manusia dari perbudakan. Upaya penghapusan budaya ini juga digambarkan oleh beberapa ayat Alquran yang menggambarkan Ialam sangat memperhatikan nilai-nilai kemanusiaan.

Hal lain seperti Ilmu pengetahuan juga sangat diperhatikan oleh Islam sebagaimana pola hidup sehat. Islam mengajarkan tentang pentingnya hidup untuk akhirat, namun tidak abai terhadap kehidupan di dunia. Dari berbagai teks hadis dan Alquran banyak mengajarkan pentingnya menjaga lingkungan, mengajarkan pentingnya memiliki etos kerja, dan pentingnya pola hidup yang lain. Hal ini menggambarkan bahwa dalam hidup terdapat ilmu-ilmu untuk menjalaninya.

\section{DAFTAR PUSTAKA}

al-Baqi, Fuad Abd. Mu'jam al-Mufahras li al-Fadh al-Quran. Beirut: Dar alFikr, 1981.

al-Hafni, Abdul Mu'in. Ensiklopedi Golongan, mazhab, pertain dan Gerakan Islam di seluruh Dunia Terj. Muhtarom. Jakarta: Grafindo, 2005.

al-Karim, Khalil Abd. Hegemoni Quraisy terj. M. Faishol Fatawi. LKiS: Yogyakarta, 2012.

Amal, Taufiq Adnan. Rekonstruksi Sejarah al-Qur'an. Yogyakarta: FKBA, 2001.

Amin, Ahmad. Fajr al-Islam, cet. ke-11. Kairo: Maktabah an-Nahdah alMisriyyah, 1975.

Anwar, Rosihon dan Shalihin, Mukhtar. Ilmu Tasaw.wuf. Bandung: Pustaka Setia, 2007.

Armstrong, Karen. Muhammad, Prophet for Our Time terj. Yuliani Liputo. Bandung: Mizan, 2013.

Badrutamam, Ahmad. "Perlindungan Anak dalam Perspektif al-Qur'an", Tesis Pasca Sarjana Universitas Islam Negeri Sunan Kalijaga Yogyakarta, 2012.

Barir, Muhammad. "Buruh dan Perbudakan dalam Perspektif alQur'an" dalam al-Quran dan Isu-Isu Sosial, Yogyakarta: Idea Press, 2014.

Engineer, Asghar Ali, Islam dan Teologi Pembebasan terj. Agung Prihantoro, Yogyakarta: Pustaka Pelajar, 2009.

Faiz, Fahruddin. Hermeneutika al-Qur'an: Tema-Tema Kontroversial, Yogyakarta: eLSAQ Press, 2011.

Hart, Michael H.. The 100 Ranking of The Most Influential Persons in History, A Citadel Press, 1992 
Hasan, Hasan Ibrahim. Sejarah dan Kebudayaan Islam, Jakarta: Kalam Mulia, 2001

Hitti, Philip K.. History of The Arabs terj. R. Cecep Lukman Yasin dkk., Jakarta: Serambi, 2010

Khaldun, Ibn. Muqaddimah terj. Ahmadie Thoha, Jakarta: Pustaka Firdaus, 2011

Mustaqim, Abdul. "Kontroversi tentang Corak Tafsir Ilmi“ dalam Jurnal Studi Ilmu-Ilmu al- Qur'an dan Hadis vol. 7, Yogyakarta, Jurusan Tafsir Hadis UIN Sunan Kalijaga, 2006

Reynolds, Gabriel Said. The Quran in Its Historical Context, Canada: Routledge, 2008

Rofiq, Choirul. Sejarah Peradaban Islam, Ponorogo: STAIN ponorogo Press, 2009

Shihab, M. Quraish Tafsir al-Mishbah vol. 13, Jakarta: Lentera Hati, 2003.

Supriyadi, Dedi. Sejarah Peradaban Islam, Bandung: Pustaka Setia, 2008

Syahruddin el-Fikri, Situs-Situs dalam alQur'an, Jakarta: Republika, 2010

Tim Departemen Agama RI, Ulum atTafsir I. Jakarta: Departemen Agama RI, 1996.

Tounbee, Arnold. Sejarah Umat Manusia terj. Agung Prihantoro dkk. Yogyakarta: Pustaka Pelajar, 2007.

Wijaya, Aksin. Arah Baru Studi Ululumul Qur'an. Yogyakarta: Pustaka Pelajar, 2009. 